\title{
Rotation or reciprocation: a contemporary look at NiTi instruments?
}

\author{
J. Prichard ${ }^{1}$
}

\section{Prichard}

(1)

\begin{abstract}
(1)
\end{abstract}
Successful root canal therapy relies on many factors, not least of all mechanical shaping. Traditionally stainless steel files were used, but the introduction of nickel titanium (NiTi) alloys significantly broadened the instrument design options available to the practitioner. NiTi has allowed manufacturers to produce larger more flexible instruments that can be used mechanically which speeds up canal preparation and reduces fatigue. However, they are relatively expensive and are susceptible to fracture. Recently the use of NiTi instruments in a reciprocating motion have been introduced which claim to reduce the fracture incidence, and negate the need for a glide path.

\section{INTRODUCTION}

Schilder ${ }^{1}$ suggested that the root canal be cleaned and then shaped to allow for three-dimensional obturation. However, mechanical and chemomechanical debridement of root canals has been shown to significantly reduce bacterial counts, but not render canals consistently bacteria free. ${ }^{2,3}$ The reason that root canal treatment works is because of the reduction in the microbial content of canal systems and therefore its pathogenicity sufficiently to promote radicular healing.

Although successful therapy depends on many factors, one of the most important steps in any root canal treatment is canal preparation. This is essential because preparation determines the efficacy of all subsequent procedures and includes mechanical debridement, creation of space for medicament delivery, and optimised canal geometries for adequate obturation. ${ }^{4}$

Mechanical instrumentation of the root canal system starts with preparation of the access cavity to identify all of the canal

\footnotetext{
${ }^{1}$ Associate Clinical Teacher and Clinical Supervisor in Endodontics, Warwick Dentistry, The University of Warwick, Coventry, CV4 7AL

Correspondence to: James Prichard

Email: james@prichard.co.uk
}

DOI: 10.1038/sj.bdj.2012.268 orifices. This can be safely achieved with the use of burs and ultrasonic instruments allowing straight-line access to the root canal system.

Once the canals have been identified they must be prepared along their entirety starting with a coronal flare which offers a couple of advantages:

1. Maintenance of working length ${ }^{5}$

2. Better tactile sensation of the apical constriction. ${ }^{6}$

As the highest concentration of bacteria exist in the coronal portion of the tooth, cleaning of the access cavity with sodium hypochlorite will allow instrumentation through clean, fresh irrigant into the infected system.

\section{MECHANICAL SHAPING}

Different methods of root canal instrumentation (which traditionally has been performed with stainless steel handfiles) have been described in the literature. The advent of nickel-titanium (NiTi) instruments has rapidly transformed the shaping process but the problem with NiTi is that it fractures or separates, ${ }^{7}$ normally for one of two reasons:

1. Torsional fracture (when the tip of the instrument gets locked into a root canal, stops rotating and breaks off)
2. Cyclic fatigue (when an instrument is rotated continuously around a curve and catastrophic opening of surface micro-cracks occurs).

Manufacturers have therefore created different instrument designs and sequences to overcome these failures, leading to a plethora of different systems available to the practitioner, ${ }^{7}$ all requiring multiple files that significantly increase the cost of root canal preparation.

\section{RECIPROCATION}

In 1985 the use of balanced forces, ie the use of clockwise and anticlockwise movements (manual reciprocation) in the preparation of root canals, was presented. ${ }^{8}$ This technique allows the use of larger stainless steel files to counter the natural canal curvature during preparation. ${ }^{9}$ However, the use of stainless steel hand files is time consuming and tiring and produces a high level of procedural errors.

The use of automated reciprocation in endodontics was introduced with the Giromatic in 1964, utilising stainless steel files moving with a 90 degree clockwise and anticlockwise motion. It was reported that these files resulted in greater procedural errors than hand filing. ${ }^{10}$ The concept 
of reciprocating files was re-introduced in $2008^{11}$ this time using single NiTi instruments (ProTaper) to shape root canals. This was shown to be as effective at cleaning around root canals as the full ProTaper system, ${ }^{12}$ and to extrude similar amounts of apical debris. ${ }^{13}$

As a result of this paper there has been a re-emergence of reciprocation and development of single file NiTi preparation systems. Reciproc (VDW) and Wave One (DentsPly) single file systems were launched in 2011.

Contemporary instrument design combined with reciprocating action promises single file root canal preparation which is less expensive than multiple file NiTi systems. The reciprocating movement occurs in an anticlockwise cutting movement purported to be 130 degrees, followed by a clockwise releasing movement of 50 degrees. This means that each instrument takes three rotations to complete a full 360 degree rotation and thus the elastic limit of the instrument is not exceeded.

This reciprocating motion has been shown to increase the number of cycles to failure when compared to continuously rotating instruments ${ }^{14}$ and demonstrate significantly higher resistance to cyclic fatigue, ${ }^{15}$ both of which increase the life of the instrument. Instrument design may also have an effect on increasing cyclic fatigue. ${ }^{16}$ Reciproc has an S-shaped crosssection similar to MTwo along its entire length while WaveOne has three radial lands in the apical $5 \mathrm{~mm}$ and then changes to a bladed design similar to ProTaper for the remaining $9 \mathrm{~mm}$.

\section{TOTALLY NEW CONCEPT}

A totally novel concept in instrument design was introduced with the Self Adjusting File (SAF - Henry Schein). The files are made of NiTi, hollow, shaped in a compressible lattice formation, and work in a vertical motion. The root canal is 'sandpapered' while being simultaneously and continually irrigated.

It has shown to be better at debriding oval root canals than rotary instruments, ${ }^{17}$ canals in maxillary molars were homogenously and circumferentially prepared with little canal transportation, ${ }^{18}$ less hard-tissue debris accumulated in isthmuscontaining root canal systems compared with instrumentation with ProTaper rotary files, ${ }^{19}$ but it does not allow for control of apical enlargement. ${ }^{20}$

My presentation at this year's BDA Conference will address these issues and allow the attendee to cut through the information available to enable the right decision to be made when investing in a file system suitable for their own practice.

1. Schilder H. Filling root canals in three dimensions. J Endod 1967; 32: 281-290.

2. Byström A, Sundqvist G. Bacteriological evaluation of the efficacy of mechanical root canal instrumentation in endodontic therapy. Scand J Dent Res 1981; 89: 321-328.

3. Byström A, Sundqvist G. Bacteriologic evaluation of the effect of 0.5 percent sodium hypochlorite in endodontic therapy. Oral Surg Oral Med Oral Pathol 1983; 55: 307-312.

4. Peters 0 A. Current challenges and concepts in the preparation of root canal systems: a review. J Endod 2004; 30: 559-567.

5. Davis R D, Marshall J G, Baumgartner J C. Effect of early coronal flaring on working length change in curved canals using rotary nickel titanium versus stainless steel instruments. J Endod 2002; 28: 438-442.

6. Stabholz A, Rotstein I, Torebinejad M. Effect of preflaring on tactile detection of the apical constriction. J Endod 1995; 21: 513-518.
7. Bauman M A. Nickel-titanium: options and challenges. Dent Clin N Am 2004; 48: 55-67.

8. Roane J B, Sabala C L, Duncanson M G. The "balanced force" concept for instrumentation of curved canals. J Endod 1985; 11: 203-211.

9. Southard D W, Oswald R J, Natkin R. Instrumentation of curved molar root canals with the Roane technique. J Endod 1987; 13: 479-489.

10. Weine F S, Kelly R F, Bray K E. Effect of preparation with endodontic handpieces on original canal shape. J Endod 1976: 2: 298-303.

11. Gared Y. Canal preparation using only one NiTi rotary instrument: preliminary observations. Int Endod J 2008; 41: 339-344.

12. De-Deus G, Barino B, Zamolyi R $Q$ et al. Suboptimal debridement quality produced by the single-file F2 ProTaper technique in oval-shaped canals. J Endod 2010; 36: 1897-1900.

13. De-Deus G, Brandao M C, Barino B et al. Assessment of apically extruded debris produced by the singlefile ProTaper F2 technique under reciprocating movement. J Endod 2010; 110: 390-394.

14. Gavini G, Caldeira C L, Akisue E, de Miranda Candeiro G T, Kawakami D A S. Resistance to flexural fatigue of reciproc R25 files under continuous rotation and reciprocating movement. J Endod 2012; online article available at $\mathrm{http}: / / \mathrm{dx}$.doi.org/10.1016/j. joen.2011.12.033 (accessed 26 March 2012).

15. Kim H C, Kwak S W, Cheung G S P et al. Cyclic fatigue and torsional resistance of two new nickeltitanium instruments used in reciprocation motion: Reciproc versus WaveOne. J Endod 2011; 38: 541-544.

16. Plotino G, Grande N M, Testorelli L, Gambarinin G. Cyclic fatigue of Reciproc and WaveOne reciprocating instruments. Int Endod J 2012; online article available at http://dx.doi.org/10.1111/j.1365-2591.2012.02015.x (accessed 26 March 2012).

17. De-Deus G, Souza E M, Barino B et al. The selfadjusting file optimizes debridement quality in oval-shaped root canals. J Endod 2011; 37: 701-705.

18. Peters $O A$, Paqué F. Root canal preparation of maxillary molars with the self-adjusting file: a micro-computed tomography study. J Endod 2011; 37: 53-57.

19. Paqué F, Al-Jadaa A, Kfir A. Hard-tissue debris accumulation created by conventional rotary versus self-adjusting file instrumentation in mesial root canal systems of mandibular molars. Int Endod $\mathrm{J} 2011$; online article available at http://dx.doi. org/10.1111/j.1365-2591.2011.01991.x (accessed 26 March 2012).

20. de Gregorio C, Paranjpe A, Garcia A et al. Efficacy of irrigation systems on penetration of sodium hypochlorite to working length and to simulated uninstrumented areas in oval shaped root canals. Int Endod J 2012; online article available at http:// dx.doi.org/10.1111/j.1365-2591.2011.01999.x (accessed 26 March 2012). 